IMREH Szabolcs

\title{
ELTÉRŐ MOTIVÁCIÓK A KIS- ÉS KÖZÉPVÁLLALKOZÁSOK HÁLÓZATI EGYÜTTMÜKÖDÉSEIBEN
}

Általános megállapítás, hogy a kis- és középvállalkozások meghatározó jelentớségúek a gazdaság fejlődésében. Az ilyen típusú vállalkozások egyik legnagyobb problémája pontosan a méretük, a kicsinység gyakran rendkívül komoly nehézségeket eredményezhet (relatíve magas tranzakciós költségek, méretgazdaságossági problémák). Erre a kihívásra adható egyik sikeres válasz a különbözó módon megvalósuló kooperációk, vállalati hálózatok. A tanulmányban a hálózati együttmúködésekhez vezetố motivációkat tekinti át a szerzố. Számos magyarázó okot lehet találni arra, hogy az egyes vállalkozások miért keresik a kooperációs lehetôségeket más társaikkal. Nagy vonalakban az együttmúködés fő́ célja olyan elónyök elérése, amelyeket egyéni erôfeszítéseikkel nem tudnak kiharcolni, még szemléletesebben fogalmazva: valamilyen kollektív hatékonyság elérése. A rendszerezés igényével a tanulmány a szerteágazó szakirodalmi háttérból megpróbálja kiemelni azokat a tényezóket, amelyeket leggyakrabban említenek, mint az együttmúködésben rejló elốnyöket a partnerek számára. Feltételezhetố, hogy mivel ezen okok jelentkeznek leggyakrabban, mint az együttmúködés magyarázói, ezért a hálózatok sajátosságait is meghatározzák. A tanulmány végén két - Szeged környékén megvalósult - primer felmérés tapasztalatait ismerteti a szerzó, bemutatva az együttmúködések természetét és a kooperációktól elvárt elónyöket.

Kulcsszavak: kis- és középvállalkozások, hálózatok, együttmúködések, hálózati motivációk, vállalkozásfejlesztési beavatkozások

Napjaink gazdaságában egyre gyakrabban jelennek meg különféle hálózatok, klaszterek, kooperációk. Az eltérő együttmúködések ,rengetegében” mind nehezebb eligazodnia a gyakorlati, illetve az elméleti szakembereknek. A vállalati hálózatot legegyszerúbb megközelítésben cégek közti kapcsolatok rendszereként definiálhatjuk (Kocsis, 2000). Ettól a vállalati gyakorlatban kialakult megoldások sokkal összetettebbek, számos különféle együttmúködési forma alakult ki az elmúlt néhány évtizedben. Markánsan jelzi a fogalom összetettségét, hogy Gummersson már a vállalati kapcsolatok rendszerét is kiterjesztette, és négy koncentrikus körben ábrázolja. Összesen harminc(!) különféle kapcsolatot definiál, amelyből csak három tekinthető „klasszikus” piaci kapcsolatnak (Veres, 1998). Már az együttmúködéseken belül is csak egy bizonyos fejlettségi fok felett beszélhetünk hálózati együttmúködésekról. A vállalatok közti kooperáció a legkülön- félébb területeken jelenik meg, lehetôséget biztosítva az együttmúködések tipizálására. A vállalkozások közötti együttmúködési formák például osztályozhatók egyrészt a kölcsönös bizalom és függés erőssége mentén, másrészt pedig a versenyképességre gyakorolt hatás alapján, számos kooperációs formát elkülönítve, az egészen laza „szövetségi formától” egészen a szoros kapcsolatokon alapuló közös termelési hálózatokig (Malecki, 1997: 181. o.). A valós gazdasági életben természetesen elófordulhatnak olyan kooperációk, amelyek minden jellemzóból felmutatnak bizonyos jegyeket. Sốt lényeges azt is kiemelnünk, hogy a vállalatok közti hálózati együttmúködések bizonyos esetekben pontosan a klaszteresedés előzményeinek tekinthetôk A megfigyelések szerint gyakran egy múködó hálózat bázisán épülnek ki nagyon sikeres klaszterek. A szakirodalmi felosztás szerint is külön csoportot képeznek a hálózatra épülő klaszterek (Imreh - Lengyel, 2002). ${ }^{1}$ 
A rövid fogalmi elhatárolás után kitérünk a hálózati kapcsolatok részletesebb vizsgálatára, meg kell jegyeznünk azonban, hogy a késóbbiekben megfogalmazott megállapítások jelentős hányada bizonyos mértékben szinte minden együttmúködési formára érvényes. Vizsgálatunkban azért a hálózati típusú együttmúködésekre fókuszálunk, mert Szeged és vonzáskörzete gazdasági fejlettségének jelenlegi szintje leginkább az ilyen együttmúködésekre teremt lehetôséget. A hálózatokat több módon lehet osztályozni, a szakirodalomban fellelhetô különféle osztályozásoknak mind a száma, mind a rendezőelve gyakorlatilag áttekinthetetlen. A szakirodalmi elemzésben kizárólag hálózati motivációk tipizálásával kapcsolatos gondolatokat szintetizálunk röviden.

\section{Hálózati alaptípusok a motivációk alapján}

Számos magyarázó okot lehet találni arra, hogy az egyes vállalkozások miért keresik a kooperációs lehetőségeket más társaikkal. Általános megállapítás, hogy a vállalkozások együttmúködésének fő célja olyan előnyök elérése, amelyeket egyéni erófeszítéseikkel nem tudnak kiharcolni (Brito, 2001), még szemléletesebben fogalmazva, valamilyen kollektív hatékonyság elérése (Schmitz, 1995).

Ehhez a gondolatkörhöz tartozik az a felismerés is, hogy a hálózati együttmúködés során a vállalkozások olyan eróforrásokat is használhatnak céljaik elérése érdekében, amelyeket nem egyénileg birtokolnak (Szerb, 2003). Hasonló definiálása a vállalati hálózatnak, hogy valójában ez a kapcsolatok egy olyan összessége, melyben a vállalkozó részt vesz, és amely számára fontos erôforrásokat biztosít (Drakopoulou Dodd - Patra, 2002).

A kapcsolatok három alapvető logika mentén szerveződhetnek, attól függően, hogy mely dimenzió a meghatározó a hálózatok kialakulásában és múködésében (Ford, 2003):

- tevékenységközpontúság: ekkor a tevékenység dominálja a múködést,

- erôforrás-központúság: az eróforrásigény határozza meg a hálózat múködését

- vállalatközpontúság: a meghatározó (integrátor) vállalat céljai határozzák meg a múködési sajátosságokat.

Ennek megfelelően a hálózati kapcsolatok sajátosságait is számos - egymással párhuzamosan fejlődő - tényező határozza meg, amely szorosan összefügg a motivációkkal. A hálózatok három „,kötelék” mentén fejlődhetnek (Häkansson - Snehota, 1995):
- tevékenységi kapcsolatok: meghatározó jelentőségú, hogy a hálózati tagok mely tevékenységeik mentén kapcsolódnak a többiekhez,

- eróforrás-kötelékek: a közösen használt eróforrások dominálják a kapcsolatokat,

- szerepkötelékek: a hálózatban tevékenykedő vállalkozások alkalmazottai is megismerik egymást, kialakulnak a hálózati múködésben betöltött szerepek, viselkedési minták. $^{2}$

Azaz a motivációknak rendkívüli jelentôsége van a hálózatok létrejöttében és formájuk, múködési sajátosságuk kialakulásában. A szerteágazó szakirodalmi háttérból megpróbáltuk kiemelni azokat a tényezóket, amelyeket leggyakrabban említenek, mint például az együttmúködésben rejlő előnyöket a partnerek számára. Az általunk használt tipizálás ebben az esetben a legtöbbet említett különböző motivációk alapján készült, mivel feltételeztük, hogy ezen okok jelentkeznek leggyakrabban, mint az együttmúködés magyarázói. A felosztás meglehetôsen hasonló a DG Enterprise által megfogalmazott tipizáláshoz (DG ENTR, 2004), azzal a módosítással, hogy a tranzakciós és a transzformációs költségek csökkentésében rejlő előnyöket - mint motivációkat - egy csoportban kezeljük.

A szakirodalomban fellelhető számos felosztás alapján az alábbi öt, alapjaiban különböző motiváció különíthető el, amelyek együttmúködésre ösztönözhetik a kis- és középvállalkozásokat (DG ENTR, 2004; Johannisson, 1997; Lechner - Dowling, 2003; ADAPT, 2001; OECD, 2004 alapján saját tipizálás):

- forrásokhoz hozzáférés, az eróforráskorlátok tágítása,

- költségelőnyök szerzése,

- jobb hozzáférés a piachoz,

• „elfogadottság” növelése, elismertség iránti vágy, illetve

- valamilyen új tudás, ismeret megszerzése.

Ezenfelül természetesen még rendkívül sok egyéb oka is lehet a vállalkozások együttmúködésének, úgy véljük azonban, hogy ezek az együttmúködési okok szinte minden kooperációnál megjelennek valamilyen súllyal. A kategóriákat a vizsgálat során a lehető legtágabban értelmeztük, az elméleti áttekintésben azonban csak a legfontosabb jellemzókre koncentrálunk. Egyre gyakoribb okként említhetô például a „hálózatosodás mint a növekedés forrása", azaz a vállalkozások a fejlődésük érdekében múködnek együtt (Lechner-Dowling, 2003). Véleményünk szerint ez alapjaiban véve nem egy speciális ok a hálózatosodásra, hanem minden profitorientált tevékenység egyik alapvetô mozgatórugója. Pontosan a fejlődés iránti vágy következményeként 
kívánnak a vállalkozások élni a fenti lehetôségekkel, hiszen az eróforráskorlátok tágításától egészen az új ismeretek megszerzéséig minden tevékenység a cég fejlôdését, de legalább fennmaradását szolgálja.

Rendkívül érdekes a motivációk fontosságának a változása, régebben inkább az ún. „kemény” tényezók (azaz a fenti tipizálásból az elsố három) kaptak nagyobb hangsúlyt a hálózatosodás magyarázó okai között. Ezzel szemben az elmúlt néhány évben az olyan „puha” - nehezen, vagy egyáltalán nem számszerúsíthetô - előnyök, mint a „valahová tartozás érzése, és a tudás ilyen módon történó terjedése", egyre jobban felértékelődnek. Természetesen nagymértékben függ az adott kis- és középvállalkozástól, illetve a hálózat tulajdonságaitól, hogy melyik motivációnak milyen jelentőség tulajdonítható.

\section{A korlátok kitágítása}

Számos tanulmány rámutat, hogy a kis- és középvállalkozások szinte minden esetben különbözô korlátokba ütköznek fejlődésük során. A hálózatosodás kialakulása gyakran az erőforráskorlátok lebontására irányul, a szakirodalomban is külön típusként különítik el az „erőforrás-kötelékeken” alapuló hálózatokat. (Ford, 2003.) Ezeket a korlátokat a legkülönfélébb módon értelmezzük, ezért gyakran nehezen határozható meg, hogy pontosan milyen akadályozó tényezố a vizsgálat tárgya. Jelen értekezésben a vizsgálatot három alapvetố, a sikeres vállalkozások múködtetésében elengedhetetlen „,erôforrástípus” áttekintésére korlátozzuk. A felosztásban végül az elméleti közgazdaságban is használt eróforrástípusokhoz nyúltunk vissza, mivel ezeket tartjuk az egész vállalkozási tevékenység alapjainak:

- A kis- és középvállalkozások hálózatosodásának egyik mozgatórugója lehet a különféle „,infrastrukturális jellegû́" korlátok lebontása. ${ }^{3}$

- Az egyik legkomolyabb probléma a kisebb cégek életében a finanszírozási problémák áthidalása, és különösen a forrásokhoz történó hozzájutás.

- Végül az ún. humán tényezók is számos esetben jelenthetnek korlátokat a vállalkozás múködésében. ${ }^{4}$

A hazai szakirodalomban is gyakran említett tényezô, illetve a meghatározó jelentôségú dokumentumokban is megfogalmazódik, hogy az együttmúködések egyik legfontosabb célja a rendelkezésre álló erôforrások megosztásán keresztül az ilyen jellegú korlátok lebontása (DG ENTR, 2004; ADAPT, 2001). Az alapvetố probléma gyakran az, hogy a kis- és középvállalkozások nem képesek megszerezni a szükséges kapacitásokat, illetve ha mégis sikerül hozzájutniuk, akkor jobbára nem képesek kihasználni ezeket. (Általános gazdaságtani megállapítás, hogy a vállalatok mindenképpen a kapacitásaik minél jobb kihasználására törekednek, rendkívül komoly versenyhátrányt jelentenek a kihasználatlan tókejószágok.) Erre a két problémára egyaránt jó megoldást kínál a kapacitások közös használata, mivel mindkét esetben képes orvosolni a cégek ilyen jellegú hátrányait. A közös kapacitáshasználat rendszeresen megvalósuló formái (hasonló nagyságú és erejú vállalkozások közösen használnak valamilyen gépet vagy berendezést) mellett rendkívül érdekes megoldások is kialakultak a piaci folyamatok következményeként. Egy érdekes formáció például a Furnitrio által kidolgozott megoldás, ahol egy nagyobb (integrátor) vállalat biztosítja a legkisebb cégek múködéséhez szükséges tárgyi eszközöket (Varamäki - Pihkala, 1997).

Meglehetôsen hasonló logikán alapszik a forrásokhoz történó jobb hozzáférés. Az egyik legkikristályosodottabb megállapítás a kis- és középvállalkozásokkal kapcsolatban, hogy a múködésük során a legnagyobb probléma a finanszírozási forrásokhoz történő hozzáférésük (Kállay, 2002). Ezek a cégek általában alultőkésítettek, és gyakran nincs módjuk külsô források bevonására (Kállay - Imreh, 2004). Az alábbiakban röviden áttekintjük, hogy milyen módon segítheti a különféle kooperációkban történő részvételük a jobb finanszírozási feltételek elérését. A kis- és középvállalkozások finanszírozása túlmutat az értekezés keretein, ebben az esetben kizárólag a hálózati együttmúködéseken belül létrejövố alternatívákra koncentrálunk. ${ }^{5}$ Az egyes lehetőségek osztályozásánál rendezőelvként a (potenciális) finanszírozó személyét követjük:

- Az egyik leggyakoribb, és a szakirodalomban egyre nagyobb hangsúlyt kapó tényezô az informális interperszonális hálózatokban történő szerepvállalás következtében megvalósuló finanszírozás. Érezhetô, hogy a „,kapcsolati tóke” segítségével gyakran jutnak forrásokhoz a kis- és középvállalkozások, ebben az esetben általában a finanszírozók családtagok, barátok, más kisvállalkozók.

- Világosan látható, hogy az „intézményesült” külső finanszírozók, azaz a pénzintézetek, illetve különböző fejlesztési ügynökségek is szívesebben hitelezik a hálózatokban tevékenykedő cégek múködését.

- Egy speciális és gyorsan terjedő finanszírozási forma az ún. vállalatközi fejlesztőtóke.

A kapcsolati tóke finanszírozásban betöltött szerepe rendkívül felértékelődött az elmúlt néhány évben, az ilyen hálózatok egyik előnyeként ezt a lehetőséget említik (Premaratne, 2001). Különösen fontos lehet az ilyen jellegú hálózatokban történő részvétel a vállalko- 
zás korai szakaszában, amikor a finanszírozás gyakran egyetlen alternatívája az ún. 3F (Founder, Family, Friends). A vállalkozások indításánál végképp elengedhetetlen az ilyen kapcsolatok megléte.

$\mathrm{Az}$,intézményesült” külsó finanszírozók szintén szívesebben finanszírozzák a különbözô együttmúködések szereplőit. Mind az egymással együttmúködő kisvállalkozások, mind pedig a nagyvállalatoknak beszállító kis- és középvállalkozások kisebb kockázatot jelentenek a finanszírozók részére, mint az egyedül tevékenykedô cégek (Hancé - Cieply, 1996). A közismert iparági körzetekben ez az egyébként is meglévő finanszírozási hajlandóság még egy bizalmi faktorral is kiegészül.

A vállalatközi fejlesztôtóke esetén éppen az együttmúködés megléte a finanszírozási forráshoz jutás közvetlen oka. Egyrészt az esetek nagyobb részében a potenciális finanszírozó már régebbi kapcsolatot ápol a finanszírozottal, piaci céljaik valószínúsíthetôen egybeesnek. Másrészt a gyakran finanszírozási akadályt jelentő információhiány ebben az esetben nem áll fenn, mivel a szereplók már ,,ismerik egymást”, ezért a kölcsönös bizalmatlanságot sem kell leküzdeni, tisztában vannak egymás eddigi tevékenységével.

Végül térjünk ki a kooperációknál rendkívül fontos humán tényezókre. Szintén gyakran hangoztatott magyarázat, hogy a kis- és középvállalkozások eredményesebb és hatékonyabb múködésének egyik legnagyobb korlátja a vállalkozó önmaga. Gyakran nem megfelelő döntéseket hoz, nincsenek elégséges információi a piaci kihívásokkal kapcsolatban, illetve a szükséges tapasztalatok hiányoznak. Az együttmúködések keretein belül, különösen az informális hálózatok segítségével ez a hátrány mérsékelhetô. A hálózati keretek között meglévő kapcsolati tốke számos esetben elônyére válhat a kisvállalkozásoknak. Segítséget nyújthat az üzleti lehetôségek felismerésében (Hills - Lumpkin - Singh, 1997; Singh et al., 1999), s gyakran a hiányzó készségek és képességek pótlásában is jelentős lehet (Johannisson, 1997). Különösen fontos a vállalkozás életének korai időszakában (Johannisson - RamirezPasillas, 2001), illetve egyre kiforrottabb szakirodalma van a társadalmi hálózatok fontosságának a vállalkozás indításához szükséges készségek megszerzésében (Hansen, 2000).

\section{Költségelönyök szerzése}

Minden piaci körülmények között tevékenykedő vállalkozás ki van téve a versenynek. Ezért nehezen képzelhetố el olyan szituáció, amelyben a költségek csökkentése ne lenne része a vállalati stratégiának. Ez a megállapítás különösen igaz a kis- és középvál- lalati szektorra, mivel méretgazdaságossági okokból hátrányban van a nagyvállalati szektorral szemben, következésképp fokozottabb figyelmet kell fordítania a költségek minimalizálására. A megfelelő formában megvalósuló hálózati együttmúködések különösen alkalmasak a költségek csökkentésére (DG ENTR, 2004). A költségek csökkentésén belül feltétlenül érdemes elkülönítenünk a tranzakciós és a transzformációs költségek mérséklését, bár kétségtelen, hogy a kooperációk mindkét költségfajta csökkentésére (,megmentésére”) alkalmasak (Mundim - Rossi - Stocchetti, 2000).

A kis- és középvállalkozások életében meghatározó jelentôségúek a tranzakciós költségek (Kállay - Imreh, 2004). Az együttmúködések során az ilyen jellegú költségek csökkenthetốk, a hálózati együttmúködések elméleti megalapozásánál többek között ezért is kap fontos szerepet a tranzakciós költségek gazdaságtana (Varamäki, 1996). Tranzakciós költségeken minden olyan költséget értünk, amely az adott üzlet létrehozása érdekében merül fel, illetve a konkrét tranzakció költségeit is. Tehát például a piac/termék/partner megkeresésnek a költségei, az ún. ex ante költségek éppúgy felmerülnek, mint az adott ügyletet terhelô ráfordítások. Egyértelmú, hogy egy megfelelő hálózat az ilyen költségek mérséklésére alkalmas, a legegyszerúbb példa a hosszú távú partneri kapcsolatok kiépítése. ${ }^{6}$ A kooperációk segítségével az ilyen jellegú keresési költségek jelentősen csökkenthetốk (DG ENTR, 2004).

A transzformációs költségek csökkentése szintén létfontosságú a kis- és középvállalkozások számára. Itt is egy „kitörési pont” a hálózati együttmúködés, mivel lehetôséget teremt a rugalmas specializációra, mindenki a megfelelő magkompetenciáival járulhat hozzá a kooperáció tevékenységéhez (Salmi et al., 2001). Ez a rugalmas specializáció általában csökkenti a résztvevốk költségeit, mivel mindenki azt a cselekményt folytatja hálózaton belül, melyben a „legerósebb". Legalább ilyen fontos azonban megjegyezni azt a tényt, hogy a megfelelố specializáció hozzásegítheti a kooperáló partnereket jobb minőségú termékek, illetve szolgáltatások elóállításához is. Ilyen értelemben nemcsak költségelónyök szerzésére alkalmas, hanem a minőségen keresztül is érdemi versenytényező rejlik a hálózatosodásban.

\section{„Jobb hozzáférés” a piacokhoz.}

Úgy véljük, talán ez a motivációs faktor a legöszszetettebb, ezt a tényezót a legnehezebb egzakt módon definiálni. Ezért a konkrét lehatárolás helyett kísérletet teszünk a fogalom legfontosabb tartalmi elemekkel történő körülírására. Ennek értelmében minden olyan előny, amely megkönnyíti a piacra jutást és/vagy a 
piacon maradást, ebbe a kategóriába sorolható, kezdve a marketing-együttmúködésektől, egészen az együtt teremthetố nagyobb hozzáadott értékig. A legfontosabb realizálható előnyök - véleményünk szerint -, a következók:

Beszállitóként szembesül olyan kereslettel is a vállalkozás, amellyel különben nem találkozna, ebben az esetben gyakran az integrátor cégen keresztül valósul meg a külpiacokra lépés koordinációja (Gereffi, 1999). A keresleti és a kínálati oldalon egyaránt jelentósebb piaci erốt tudnak kifejteni az együttmúködő cégek, azaz az együttmúködés következtében olyan feltételek mellett tudják beszerzéseiket bonyolítani, illetve olyan piacokra is eljutnak, amelyeket egyedül képtelenek lennének elérni. Egyszerúbben fogalmazva, az együttmúködés során a cégek piaci lehetőségei bővülnek (Elfring - Hulsing, 2003). Számottevően jobb és hasznosabb piaci információkhoz juthat. Ez a tényezó szorosan kapcsolódik a fentiekhez, szemléletesen a „lehetőségek bővülése” és a „megszerzett ismeretek” között helyezkedik el. Általános tapasztalat, hogy az információs korlátok lebontására alkalmasak a különféle együttmúködések (DG ENTR, 2004; ADAPT, 2001). A kooperációk során nagyobb hozzáadott érték teremthetó, amely hozzájárul a jobb piaci eredmények eléréséhez a magasabb minôségú termékek értékesítése révén (Pietrobelli - Rabelotti, 2004). A hozzáadott érték kooperációkon keresztül történő növelése megvalósulhat a termékfejlesztéstôl kezdve egészen a különböző szektorok közötti együttmúködések keretein belül létrejövő fejlesztésekig (Humphrey - Schmitz, 2002).

A jobb piaci lehetőségek megszerzése tehát az egyik legfontosabb mozgatórugója a vállalkozások közötti együttmúködésnek. Az ilyen közvetlenül realizálható előnyök mellett azonban számos más, ún. puha tényezókön alapuló - motivációs típus is megfigyelhetô. Ezekben az esetekben közvetettebb módon profitálnak a cégek az együttmúködésekból. A továbbiakban ezek közül tekintjük át a két legjelentősebbet.

\section{$A z$,elfogadottság” növelése}

Egyre jelentôsebb motivációs tényezố a vállalkozások számára, hogy a hálózatokban történô részvétel hozzájárulhat a cégról kialakuló kép formálásához. Sôt egyre gyakoribb vélemény, hogy a „minőségi” kooperációkhoz való tartozás szinte egy márkajelzés, amely a potenciális partnerek, és különösen a vevők irányába jelent pozitív üzenetet. Különösen az induló vállalkozások esetén értékelődnek fel az ilyen típusú ún. „reputációs hálózatok”. Meg kell jegyeznünk, hogy az ilyen hálózatok gyakran átfedik egymást a késóbbiekben tárgyalásra kerülő KIT-hálózatokkal
(Knowledge, Innovation, Technology). A tapasztalatok alapján nagymértékben elósegítik a kezdeti nehézségek leküzdését az induló vállalkozások számára. Szemléletesen fogalmazva, ha nincs valami kiemelkedő rangú partnere az adott cégnek, gyakran nehezen éli túl a kezdeti időszakot (Lechner - Dowling, 2003). További jelentôsége a minôség garantálása az ilyen partner(ek) által, amely újabb kapcsolatok kialakításában is nagy segítséget nyújt a résztvevốknek. Az ilyen kooperációk jelzik a többieknek, hogy az adott cég egy megbízható partner lehet. Az empirikus felmérések is igazolják, hogy a kooperációk elôsegítik a vállalkozásokat mind a minőségi, mind a mennyiségi lehetőségek elérésében, sốt az ilyen kapcsolatok hiánya egyenesen az akadályok fokozódásához vezet (Lechner - Dowling, 2003). (Valószínúleg itt meg pontosan a potenciális partnerek bizalmatlanságának leküzdése lehet a kulcsmotívum.) Szintén hasonló megfontolásokkal szerepel a „legitimitást biztositó" hálózatok kérdése, melyek különösen az induló innovatív kis- és középvállalkozások számára jelentenek segítséget elismertségük és elfogadottságuk megszerzéséhez. Gyakran az ilyen cégek esetén valamilyen felsőoktatási intézménnyel vagy kutatóintézettel történô együttmúködés biztosítja a további kapcsolatok kiépítéséhez szükséges legitimitást (Elfring - Hulsink, 2003). Végiggondolva napjaink gyorsan változó gazdaságának természetét, illetve a potenciális partnerek gyakorlatilag végtelen számát, az ilyen típusú hálózatoknak az a legnagyobb jelentősége, hogy segítenek leküzdeni a - teljesen természetes - bizalmatlanságból adódó korlátokat.

\section{Valamilyen új tudás, ismeret megszerzése}

Kevés olyan területe van a vállalkozások közötti együttmúködések vizsgálatának, amely akkora hangsúlyt kapott volna a szakirodalomban, mint a hálózatosodás útján megszerezhetô új ismeretek. Számos különböző elnevezést alkalmaznak a hazai és nemzetközi szakirodalomban, kezdve a tanulóhálózatoktól egészen az egyre népszerúbb KIT mozaikszóval jelölt kooperációkig (Knowledge, Innovation, Technology). A KIThálózatokban mindig valamilyen új tudás, készség, képesség megszerzése vagy létrehozása a partnerség létrejöttének alapvető oka (Lechner - Dowling, 2003). Értelemszerúen az ilyen jellegú együttmúködések leginkább az innovatív vállalkozások között alakulnak ki, tágabban értelmezve azonban minden új ismeret megszerzésére irányuló együttmúködés ide sorolható.

Az együttmúködések keretein belül megvalósuló tanulási-információáramlási folyamatokat három, egymással szorosan összefüggő tényezó befolyásolja (Vilmányi, 2003; Mäkinen, 2002; Rickne 2001): 
- a kooperációkban részt vevố szervezetek tulajdonságai, kezdve az általuk birtokolt eróforrásoktól, egészen a rendelkezésükre álló szervezeti tudásig,

- az együttmúködések jellemzői (tartalmuk, innovatív jellegük, a kapcsolatok szorossága, az együttmúködés „kora”),

- az együttmúködések során egymásra gyakorolt hatások az interdependenciák, a realizálható előnyök.

Anélkül, hogy részleteiben tárgyalnánk a tanulóhálózatok legfontosabb sajátosságait, meg kell említenünk, hogy a hálózatok esetén egy érdekes és meglehetôsen egyedi megoldás kerül egyre gyakrabban elótérbe, amelyre talán a legtalálóbb elnevezés az ,interakciókon keresztül történó tanulás” (Propis, 2002).

A hálózati motivációk lehetséges tipizálásai után vizsgáljuk meg, hogy a Szeged környéki vállalkozások milyen attitúddel viselkedtek az együttmúködésekkel kapcsolatosan két különböző kutatás során.

\section{Hálózatosodás a gyakorlatban - két szegedi kutatás}

A felhasznált primer kutatások mindkét esetben egyegy nagyobb kutatás résztémái. Jelen tanulmányban kizárólag szúken értelmezett releváns részek kiragadására szorítkozunk. Tisztában vagyunk azzal, hogy - mivel nem ezen kérdések vizsgálata volt a primer kutatások központi célja - a kapott eredmények is fenntartásokkal kezelhetốk. Mindkét esetben több érdekes eredmény jelent meg a kiértékelések során, amely egy jellemző ,pillanatfényképet” ad a Szeged környéki létező és potenciális együttmúködésekról, illetve ezek ösztönzésének kérdéseirôl. Az egyik esetben a kutatás keretében 2004 júliusa és októbere között közel 700 vállalkozásnak küldtünk ki kérdőívet. ${ }^{7}$ A megkérdezett vállalkozások kiválasztásánál több szempontot is figyelembe vettünk a kutatás alapcéljai függvényében. A kérdőívezést az esetek egy részében kiegészítette egy személyes interjú is, mely keretein belül összességében harminc céggel részletesebben is elbeszélgettünk az eddigi tapasztalataikról, és különösen az általuk érzékelt jövơbeni lehetôségekról. A másik kutatás során a kérdőíves felmérés 2006-ban zajlott, és a szegedi tudásintenzív kisvállalatokat vizsgálta. ${ }^{8}$ A 401 elemú minta reprezentatív a helyi tudásintenzív vállalati szektorra. A tudásintenzív szektor lehatárolása során a nemzetközi vizsgálatok módszertanának megfelelôen az adott vállalkozás TEÁOR szerinti fơ tevékenységét használtuk. Az így létrejött 2300 céget magában foglaló alapsokaságból véletlen mintavétel során választódott ki a vizsgált minta.

\section{A hálózatosodási hajlandóságról}

A 2004-es kutatásban egy általános képet rajzoltunk a térségben múködő vállalkozásokról, amelybe beletartozott többek között az innovativitásuk vizsgálata, illetve a vállalkozásfejlesztési szolgáltatásokkal kapcsolatos viszonyuk is. Bizonyos vállalkozások meglehetősen „hasonlóan viselkedtek”, ezért az empirikus vizsgálat további része a lehetséges klaszterek azonosítását jelentette, majd a kialakított klasztereken belül kíséreltük meg a vállalkozások alapvetố karakterisztikáját, illetve a jellemző szolgáltatási igényeket megadni. A 170-es mintából elsóként kivettük a 14 nagyvállalatot, majd azokat a vállalkozásokat, amelyek nem válaszoltak valamely, a klaszterelemzés alapjául szolgáló kérdésre. Így egy 146 elemú kis- és középvállalkozásokból álló mintával dolgoztunk tovább.

A klaszterek kialakításánál két származtatott változót vettünk figyelembe: a vállalkozás innovativitását, illetve, hogy vett-e valaha igénybe vállalkozásfejlesztési szolgáltatást valamely erre hivatott megyei szerve-

1. táblázat

Klaszterek az innovativitás és a vállalkozásfejlesztési programokban való részvétel alapján

\begin{tabular}{|c|c|c|c|c|c|}
\hline & & & $\begin{array}{l}\text { Klaszter } 1 \\
\text { Érdeklódók }\end{array}$ & $\begin{array}{c}\text { Klaszter } 2 \\
\text { Innovatívak }\end{array}$ & $\begin{array}{r}\text { Klaszter } 3 \\
\text { Bezárkózók }\end{array}$ \\
\hline \multirow{4}{*}{ Innovatív-e a vállalkozás? } & Igen & $\mathrm{N}$ & 0 & 48 & 0 \\
\hline & & $\%$ & $0 \%$ & $100 \%$ & $0 \%$ \\
\hline & $\mathrm{Nem}$ & $\mathrm{N}$ & 38 & 0 & 60 \\
\hline & & $\%$ & $100 \%$ & $0 \%$ & $100 \%$ \\
\hline \multirow{4}{*}{$\begin{array}{l}\text { Vett-e korábban igénybe } \\
\text { vállalkozásfejlesztési szolgáltatást? }\end{array}$} & Igen & $\mathrm{N}$ & 38 & 30 & 0 \\
\hline & & $\%$ & $100 \%$ & $62,50 \%$ & $0 \%$ \\
\hline & $\mathrm{Nem}$ & $\mathrm{N}$ & 0 & 18 & 60 \\
\hline & & $\%$ & $0 \%$ & $37,50 \%$ & $100 \%$ \\
\hline
\end{tabular}

Forrás: saját szerkesztés 
zettól. ${ }^{9}$ Az elsôdleges kiértékeléshez hasonlóan innovatívnak tekintettünk egy vállalkozást, amennyiben az alábbiak közül legalább az egyik teljesül:

- van saját $\mathrm{K}+\mathrm{F}$ részlege,

- az elmúlt évben adtak K+F megbízást valamely külső cég részére,

- valamely külföldi partnerrel tartósan együttmúködnek termék- vagy technológiafejlesztésben.

Az elsô klaszterbe kerültek azok a vállalkozások, amelyek nem innovatívak, de már vettek igénybe vállalkozásfejlesztési szolgáltatást (1. táblázat). Óket neveztük „érdeklódóknek”. Az ide tartozó 38 kis- és nagyobb mértékben érdeklódnek a hálózatosodásban rejló elónyök iránt. Ebben az esetben egyértelmúen teljesültek a várakozások, számos jel mutat arra, hogy ezek a cégek alkalmasabbak lehetnek a hálózatösztönzési beavatkozások fogadására. Ezt a tényt igazolja többek között, hogy az innovatívnak tekintett vállalkozások $40 \%$-a nyilatkozott úgy, hogy valamely vállalatcsoportnak tagja (2. táblázat). Úgy túnik tehát, hogy a vállalatcsoporthoz tartozás fontos forrása az innovációnak, annál is inkább, mert ezen cégek $60 \%$-a nem stratégiaformáló pozícióban van a vállalatcsoporton belül. Ezt megerôsíti, hogy a másik két klaszter esetén igen kevés vállalkozás tartozik vállalatcsoportba.

Formális és informális együttmúködések

\begin{tabular}{|l|c|c|c|}
\hline & $\begin{array}{c}\text { Érdeklódók } \\
\text { \% }\end{array}$ & $\begin{array}{c}\text { Innovatívak } \\
\%\end{array}$ & $\begin{array}{c}\text { Bezárkózók } \\
\%\end{array}$ \\
\hline Vállalatcsoport tagja & 15,6 & 40,0 & 11,5 \\
\hline Beszállítói tevékenységet végez & 35,3 & 48,9 & 53,7 \\
\hline Gyakori közös marketingtevékenység más helyi cégekkel hazai piacokon & 16,2 & 10,6 & 3,5 \\
\hline Gyakori közös marketingtevékenység más helyi cégekkel külpiacokon & 11,4 & 9,3 & 1,9 \\
\hline Részt vett 2000 óta valamilyen hálózatszervezési akcióban & 10,5 & 20,8 & 8,3 \\
\hline Vezetó munkatársak többsége az SZTE-n szerezte elsó diplomáját & 18,4 & 36,2 & 12,5 \\
\hline Rendszeres szakmai kapcsolat egyetemi oktatókkal, kutatókkal & 32,4 & 39,6 & 15,8 \\
\hline Rendszeresen fogadnak szakmai gyakorlatra SZTE-s hallgatókat & 28,9 & 25,0 & 13,3 \\
\hline A vállalat valamely tisztségviselóje tag valamilyen helyi választott bizottságban & 15,8 & 25,5 & 12,3 \\
\hline
\end{tabular}

Forrás: saját szerkesztés

középvállalkozás a minta cégeinek 26\%-át jelenti. A második klaszterbe kerültek az „innovatív vállalkozások", a minta 33\%-a (48 vállalkozás). A harmadik klaszterbe azon cégek tartoznak, amelyek nem innovatívak, és nem vettek igénybe korábban vállalkozásfejlesztési szolgáltatást. Ezeket „bezárkózóknak” neveztük (60 vállalkozás, a minta $41 \%$-a). Természetesen a vállalkozások klaszterek közti megoszlása csak a minta jellemzőire, és nem a valós gazdasági szerkezetben elfoglalt arányukra utal. A klaszterek ismeretében az együttmúködések vizsgálata két részre tagolódik. Egyrészt kísérletet tettünk a vállalkozások formális és informális kapcsolatainak feltérképezésére, másrészt arra kerestük a választ, hogy egy újitás bevezetése kapcsán együttmúködik-e a vállalat valamely partnerével, és mekkora gyakorisággal.

A primer adatok elsôdleges elemzése is sejtetni engedte, hogy az innovatív cégek ,hajlamosabbak” a különféle kooperációkra, és az átlagosnál többre értékelik a hálózatosodásban rejlő elônyöket. Azaz feltételeztük, hogy a vizsgált vállalati körön belül az innovatív cégek
A vállalkozások meglepóen magas százaléka nyilatkozott úgy, hogy végez beszállítói tevékenységet, ám ez itt nem feltétlenül jelenti valamely beszerelhetô alkatrész vagy részegység beszállítását, inkább a rendszeres vevő-szállító viszonyok meglétére utal. A bezárkózó vállalatok több mint fele rendelkezik saját elmondása szerint ilyen kapcsolatokkal, így feltételezhetô, hogy a stabil vevô-szállító kapcsolatok egy jelentős része egyértelmúen a bezárkózás irányába, és az innovativitás ellen hat. A várakozásoknak megfelelóen a marketing-együttmúködések igen szórványosak valamennyi klaszter esetén. A vizsgálatban különös figyelmet fordítottunk az egyetemi kapcsolatokra, mivel a térség gazdasági szerkezete alapján valószínúsíthetóek lennének az ilyen jellegú kapcsolatok. Már az elsődleges elemzések során érzékelhetô volt, hogy ezen várakozások nem teljesülnek. Feltételezhetô azonban, hogy az innovatív cégek esetén ez a tendencia másként alakul. A várakozásaink csak részben teljesültek, az adatok alapján az innovatív cégek sem kapcsolódnak túl szorosan a tudásközponthoz. Az egyetemhez kötő- 
dő formális és informális kapcsolatok az eredmények szerint nem túl intenzívek. Az innovatív vállalkozások ilyen irányú kapcsolatai némiképp intenzívebbek, míg a bezárkózók klasztere esetén esetlegesnek túnnek. A minta innovatívnak tekintett vállalkozásai közül mintegy $40 \%$ áll rendszeres szakmai kapcsolatban valamely egyetem oktatójával, kutatójával, amely az esetek mintegy 20\%-ában térségen kívüli kapcsolatot jelöl. A formális kapcsolatok jelen esetben csak szerény mértékben ellensúlyozhatók személyes kapcsolatokkal. Erre utal például az a tény, hogy a vezetố munkatársak igen kis százalékban szerezték elsố diplomájukat Szegeden, amely a helyi informális kapcsolati háló egy igen fontos elemének hiányáról tesz tanúbizonyságot. Az esetek egy részében - valószínúleg a bezárkózók és részben az érdeklődók esetén - a kapott értékek arra is utalhatnak, hogy nincsen felsőfokú végzettséggel rendelkezô vezetô munkatárs a cégnél. Szintén a kooperációs lehetôségek hiányára utal, hogy a helyi gazdasági életben szereppel bíró testületek ${ }^{10}$ választott bizottságaiban a cégek igen kis százaléka képviselteti magát. Míg az innovatívak klasztere esetén ez a vállalkozások negyedét jelenti, addig a másik két klaszterben 10\%hoz közeli értékeket kaptunk.

Úgy véltük, hogy az együttmúködések egy fontos területe lehet, ha a kooperáció valamilyen újitás kidolgozására irányul. Különösen az innovatív cégektől várható el fokozott aktivitás ezen a területen, mivel tevékenységük szervesen kapcsolódik valamilyen új tudás teremtéséhez. Részletesen vizsgáltuk, hogy a klaszterek tagjai kikkel múködnek együtt ezen a területen. Talán ezen a területen ért bennünket az egyik legnagyobb meglepetés, ugyanis a hipotézis gyakorlatilag nem igazolódott. Bár bizonyos kooperációk megfigyelhetôk, alapjaiban véve az újítások kidolgozása kapcsán a rendszeres együttmúködések egyszerüen hiányoznak (3. táblázat).

A táblázat alapján kijelenthetô, hogy a mintában szereplő vállalkozások (és még az innovatív cégek sem!) nem hajlandók rendszeresen kooperálni valamilyen újítás létrehozása érdekében. Egyedül a megrendelővel
3. táblázat

Rendszeres együttmúködés valamely szervezettel egy-egy újítás kidolgozásában

\begin{tabular}{|l|c|c|c|}
\hline & $\begin{array}{c}\text { Érdeklódók } \\
\text { \% }\end{array}$ & $\begin{array}{c}\text { Innovatívak } \\
\text { \% }\end{array}$ & $\begin{array}{c}\text { Bezárkózók } \\
\text { \% }\end{array}$ \\
\hline Versenytárs & 9,7 & 0 & 6,3 \\
\hline Megrendeló & 17,2 & 20,5 & 16,7 \\
\hline Tanácsadó cég & 12,9 & 4,4 & 2,2 \\
\hline Beszállító & 17,2 & 0 & 13,0 \\
\hline Felsốoktatási intézmény & 6,7 & 13,6 & 4,3 \\
\hline Egyéb kutatóintézet & 0 & 9,1 & 2,2 \\
\hline
\end{tabular}

Forrás: saját szerkesztés

való kapcsolat mutat figyelembe vehetô értékeket, ám itt is a legmagasabb érték csupán a cégek $20 \%$-át jelöli (az innovatív klaszter vállalkozásai közt). A felsőoktatási intézményekkel történő együttmúködések ritkák, ami megerősíti azon korábbi eredményeket, amelyek szerint Magyarországon az egyetem és a vállalati szféra együttmúködéseiben a nagyvállalati kapcsolatok dominálnak.

\section{Az egyes motivációtípusok fontossága a kooperációkban}

A 2006-os kutatásban már közvetlenül rákérdeztünk a különféle hálózati motivációkra. Az elméleti részben részletesen vizsgáltuk a hálózatok legfontosabb sajátosságait, illetve külön kitértünk az együttmúködések lehetséges okaira. Úgy véljük, hogy az általunk vizsgált tudásintenzív kisvállalatok esetén különösen fontosak a különféle kooperációk. Ebben a felmérésben többek között - az elméleti részben szereplő kategóriákkal összhangban - arra kerestük a választ, hogy milyen okokból hajlamosak a cégek az együttmúködésre.

Közvetlenül értékelni kellett egy hetes skálán, hogy a különféle együttmúködésból realizálható elônyöknek mekkora fontosságot tulajdonít a válaszadó. A realizálható elônyöknek tulajdonított értékek között lényeges eltérések tapasztalhatók (4. táblázat).

4. táblázat

Hálózatban történố részvétel motivációi (1-7 skálán)

\begin{tabular}{|l|c|c|c|c|c|c|c|c|c|}
\hline & $\mathbf{1}$ & $\mathbf{2}$ & $\mathbf{3}$ & $\mathbf{4}$ & $\mathbf{5}$ & $\mathbf{6}$ & $\mathbf{7}$ & Összesen & Átlag \\
\hline Eróforráskorlátok tágítása & 40,7 & 9,5 & 8,8 & 8,0 & 9,0 & 10,1 & 13,8 & 100 & 3,21 \\
\hline Költségelónyök szerzése & 36,5 & 5,5 & 7,3 & 7,8 & 11,1 & 11,3 & 20,4 & 100 & 3,67 \\
\hline $\begin{array}{l}\text { Új megrendelésekhez, } \\
\text { beszerzési lehetóségekhez jutni }\end{array}$ & 20,4 & 3,0 & 7,8 & 6,3 & 11,3 & 13,6 & 37,5 & 100 & 4,76 \\
\hline Elfogadottság növelése, elismertség iránti vágy & 19,1 & 2,3 & 5,8 & 10,3 & 13,9 & 15,9 & 32,7 & 100 & 4,76 \\
\hline Új tudás, ismeret megszerzése & 16,1 & 1,5 & 4,5 & 10,1 & 15,1 & 16,9 & 35,8 & 100 & 5,00 \\
\hline
\end{tabular}

Forrás: saját szerkesztés 
$\mathrm{Az}$ adatok értelemszerúen egy pillanatnyi képet mutatnak, amely során számos (megalapozott és megalapozatlan) következtetés levonható. Ezektól most eltekintünk, esetleg arra világítunk rá, hogy a vállalkozások milyen jelentős hányada tulajdonít rendkívül kis fontosságot a költségelónyök megszerzésének és
Az együttmúködések léte mellett a kooperáció szorosságát is vizsgáltuk, rákérdezve a tranzakciók rendszerességére is. Természetesen a mintában szereplő cégek rendkívül eltérôen ítélték meg a kooperációkban rejlő lehetôségeket, és ez érzékelhetố a mindennapi üzletviteli gyakorlatukban is (5. táblázat).

\section{Új tudás (üzleti és technológiai) megszerzése érdekében mely szereplókkel} múködik együtt (\%)

\begin{tabular}{|l|c|c|c|c|c|c|}
\hline & Soha & $\begin{array}{c}\text { Kb. } \\
\text { éves } \\
\text { gyakori- } \\
\text { sággal }\end{array}$ & $\begin{array}{c}\text { Évente } \\
\text { néhány } \\
\text { alkalommal }\end{array}$ & $\begin{array}{c}\text { Havi } \\
\text { rendsze- } \\
\text { rességgel }\end{array}$ & $\begin{array}{c}\text { Heti } \\
\text { rendsze- } \\
\text { rességgel }\end{array}$ & $\begin{array}{c}\text { Összesen } \\
\text { Vevók }\end{array}$ \\
\hline Szállítók & 34,1 & 8,6 & 13,6 & 22,7 & 21,0 & 100,0 \\
\hline Azonos iparágban tevékenykedó más vállalatok & 30,2 & 14,9 & 26,7 & 21,9 & 6,3 & 100,0 \\
\hline Vállalatcsoporton belüli vállalatok & 74,1 & 8,9 & 5,6 & 5,8 & 5,6 & 100,0 \\
\hline Felsóoktatási intézmény & 54,7 & 20,7 & 14,9 & 6,0 & 3,8 & 100,0 \\
\hline Kutatóintézet & 77,0 & 11,4 & 5,8 & 4,0 & 1,8 & 100,0 \\
\hline Ügynökségek és szakmai szervezetek & 49,4 & 21,2 & 19,4 & 8,6 & 1,5 & 100,0 \\
\hline $\begin{array}{l}\text { Személyes ismerósök (informális kapcsolatokon } \\
\text { keresztül) }\end{array}$ & 13,1 & 6,3 & 28,9 & 29,6 & 22,1 & 100,0 \\
\hline
\end{tabular}

Forrás: saját szerkesztés

az erőforráskorlátok tágításának. Áttekintve a táblázatot egy rendkívül markáns eredményt figyelhetünk meg, felértékelódnek a „puhább hálózati motivációk”. A szakirodalomban ismertetett folyamatok a mintában szereplő tudásintenzív kisvállalatok esetén is jelentkeznek. Míg régebben - fóleg a hagyományos hálózatok esetén - inkább a kézzelfogható előnyök vezettek együttmúködéshez, addig a tudásalapú kapcsolatok esetén a lágyabb kategóriák értékelődnek fel. Ezt jól érzékeltetik a kapott eredmények is (elfogadottság növelése, elismertség iránti vágy: 4,76; új tudás, ismeret megszerzése: 5,00), amelyek jól jelzik a tényezóknek tulajdonított fontosságot.

Ennek a kutatásnak a keretein belül is vizsgáltuk a kooperációk egyik kitüntetett célját. Gyakori jelenség napjaink gazdaságában, hogy a vállalkozások együttmúködnek valamilyen speciális cél elérésében, ez különösen jellemző például a különböző fejlesztési elképzelések esetén. Ezért a vállalatoktól azt kérdeztük meg, hogy együttmúködik-e rendszeresen valamely más szervezettel egy-egy innováció kidolgozásában. Feltételeztük, hogy a tudásintenzív kisvállalatok komoly figyelmet tulajdonítanak az ilyen kooperációknak. Számos potenciális partner szerepére rákérdeztünk az új tudás megszerzésében.
Annak ellenére, hogy rendkívül heterogén válaszokat adtak a mintában szereplő vállalkozások, néhány alapvetố következtetés mindenképp levonható. Mindenekelótt ki kell jelenteni, hogy még a tudásintenzív kisvállalatoknak is van egy része, amely nem ismeri fel a kooperációkban rejló elónyöket, és ezért gyakorlatilag senkivel sem hajlandóak együttmúködni. Hasonlóan jól érzékelhető az informális kapcsolatok (informális hálózatok!) fontossága az új tudás megszerzésében. Gyakorlatilag az egyik legrendszeresebb formát jelenti a válaszadók szerint. Viszonylag rendszeresnek tekinthetók a piaci szereplókkel történó együttmúködések, ezen belül is a leghatározottabban az értéklánc mentén kialakuló, vevókkel és szállítókkal felépített kapcsolatok. Valószínúsíthetóen ezek a kapcsolatok szerveződnek szigorúan piaci alapokon, a kölcsönös elônyök felismerése mentén. Sajnos itt is érzékelhetô a felsóoktatási intézmények és a kutatóintézetek ,elutasitása” a tudásintenzív kisvállalatok részéról. A minta több mint fele a „soha” lehetőséget jelölte meg az új tudás megszerzésére irányuló kapcsolatokra, azaz bár ez várható lenne, még ezen a területen is abszolút nem múködnek együtt a kutatói szférával. Ez összhangban van az előzőekben tett megállapításokkal az „egyetem-üzleti” kapcsolatok elégtelen voltára nézve. 


\section{A motivációkkal kapcsolatos következtetések}

Sajnos a „pillanatfelvételek” egyértelmúen rámutattak, hogy a térségben tapasztalható együttmúködések szigetszerúek, szervezetlenek, és a vállalkozások kis hányadát érintik. Ezért feltétlenül szükséges lenne a legjobb gyakorlatok megismerése és a kooperációk tudatos ösztönzése. Az együttmúködések sokszínúsége következtében természetesen meglehetôsen nehéz egyedi jellemzóket ismertetni, a sikeres hálózatok esetén azonban az esetek nagy többségében megfigyelhetốk bizonyos sajátosságok. Az elsố sikertényezô a szereplók elkötelezettsége és az, hogy a partnerek világosan artikulálják céljaikat és elvárásaikat már az együttmúkködés elején (ADAPT, 2001). Általános tapasztalat, hogy a hálózati együttmúködési formában a piaci szemléletnek kell érvényesülnie. A második sikertényezó a szereplók meggyózése az együttmúködés hasznosságáról. Gyakran nem könnyú elfogadniuk, hogy a rendelkezésükre álló erőforrásokat, tudást meg kell osztaniuk a kooperáció többi tagjával. Általában a potyautasoktól való félelem és a kölcsönös bizalmatlanság jelenti a legjelentősebb gátat az együttmúködések kialakulásában. Pontosan ezért nem lehet eléggé hangsúlyozni az informális hálózatok fontosságát az együttmúködések sikerességében (Kingsley - Malecki, 2004). Szintén fontos tényezô a közös vízió kijelölése a kooperációs hálózatokban. Pontosan definiálni kell, hogy az együttmúködés mire irányul, és ezt a célt el kell fogadnia az összes szereplőnek. Ennek hiányában nem valósulhat meg a közös ismeretszerzés és az egymástól történố tanulás. Végül ki kell emelni, hogy az esetek jelentôs részében az ilyen hálózatokban nem csak profitorientált vállalkozások szerepelnek. Gyakran különböző felsôoktatási intézmények, kutatóintézetek is jelentôs szerepet kapnak az együttmúködésekben. A tapasztalatok azt mutatják, hogy az ilyen kooperációknak nyitottaknak kell lenniük a további partnerek bevonására, sốt kimondottan ösztönözni kell a további szereplók bevonását a hálózatba (ADAPT, 2001). Megvizsgálva a különféle motivációtípusokat, kijelenthető, hogy alapjaiban véve szinte minden együttmúködés valamilyen - közvetlen vagy áttételes - módon költséghatékonyabb megoldások elérésére irányul. A kooperációk eredendő mozgatórugója a versenyképesség növelése a különbözó típusú költségek csökkentése útján, esetleg a bevétel maximalizálásán keresztül. Ez a megállapítás a gazdaságfejlesztési beavatkozások mélyebb értelmezésében döntô jelentôségú. Szintén alapvető bármilyen kooperációnál a megfelelő bizalom megléte (Patik, 2004). Kulcsfontosságú annak a ténynek a felismerése, hogy a hálózatosodás bizalmi kapcsolaton kell, hogy alapuljon. Pontosan ezért azon területeken alakulnak ki a legsikeresebb együttmúködések, ahol a vállalkozói kultúrának fontos részét képezi a kooperációra való hajlandóság (Patik, 2006). Nem véletlen, hogy a meghatározó hálózatfejlesztési javaslatok szinte mindig komoly fontosságot fordítanak az elkötelezettség növelésére és a bizalomépítésre (Rosenfeld, 2002; Huggins, 2000). Ezért, ha a hálózatok ösztönzésére egy vállalkozásfejlesztési beavatkozásként tekintünk, akkor fel kell ismernünk, hogy az együttmúkködések létrejöttét és sikeres fennmaradását alapjaiban befolyásolják a kooperáló szereplők motivációi. Így a sikeres hálózatösztönzés legelsố lépése a potenciális tagok elvárásainak és motivációinak minél alaposabb feltérképezése.

\section{Összegzés}

A tanulmányban a hálózati együttmúködésekhez vezetô motivációkat tekintettük át. Számos magyarázó okot lehet találni arra, hogy az egyes vállalkozások miért keresik a kooperációs lehetôségeket más társaikkal. Megállapításaink alapján gyakorlatilag öt egymástól eltérố motivációra vezethetók vissza a kooperációk, többek között kezdve az erőforrás-korlátok tágításától, a költségelőnyök szerzésén keresztül, egészen az „elfogadottság” növeléséig. Ezt követôen két, a közelmúltban lezajlott primer kutatás eredményeit ismertettük. Mindkét esetben több érdekes eredmény jelent meg a kiértékelések során, amely jellemző ,pillanatfényképet” adott a Szeged környéki létezô és potenciális együttmúködésekról, illetve ezek ösztönzésének kérdéseiról. Az együttmúködések alacsony szintjét, és általánosságban a kooperációknak tulajdonított csekély fontosságot jól érzékeltették megfigyeléseink.

A tanulmányban végül rávilágítottunk, a motivációk megismerése a hálózatok létrejöttének támogatására irányuló vállalkozásfejlesztési beavatkozások során is jelentôséggel bír. A vállalkozások együttmúködési hajlandóságának fokozásánál világosan rá kell mutatni, hogy melyek azok a közvetlen, és melyek azok a csak késóbbiekben jelentkezó költségelőnyök, melyeket a kooperációk során realizálhatnak. Ennek ismeretében már csak a potenciális szereplók piaci döntésein múlik az együttmúködés léte, azaz, ha sikerült megvilágítani az előnyöket, és ez elegendő a cégeknek, akkor érdemi és hosszabb távon fennmaradó kooperációk jönnek létre. Ellenkezô esetben viszont valószínúsíthetôen csak a fejlesztésre szánt források elherdálása történik meg. Éppen ezért fontos, hogy a különböző hálózatszervezési akciók kidolgozásakor pontosan tisztában legyünk a szereplók elvárásaival és az általuk realizálható elónyökkel. 


\section{Jegyzetek:}

${ }^{1}$ Reményeink szerint pontosan ebbe a körbe fognak tartozni a Szegedi Tudományegyetem köré szerveződő innovatív kis- és középvállalkozások hálózatai, amelyek a későbbiekben kialakuló klaszterek előfutárai lehetnek.

${ }^{2}$ Gyakran ezek a személyi kérdések döntő jelentôségúek egy hálózat sikeres múködésében.

3 A tipizálásban szándékosan kerültük a „tốke” kifejezést, mivel - a pontatlan használat következtében - gyakran félreértésre ad okot. Az elemzésben világosan el akartuk különíteni a finanszírozási (pénzügyi) kérdésektől.

${ }^{4}$ A humán tényezóket itt kissé másképp értelmezzük, mint az elméleti közgazdaságban teszik, ide soroljuk a szaktudástól egészen a vállalkozói készségig az összes (emberi) tényezót.

5 A vizsgálat tárgyát azok a gyakorlatok képezik, melyek esetében a cégek jobb finanszírozási feltételekkel szembesülése, illetve egyáltalán forráshoz jutása hálózati létüknek köszönhetô.

${ }^{6}$ Nem véletlen, hogy a modern üzleti menedzsmentben egyre gyakoribb például az ilyen kooperációk kiépítése a szállítókkal, míg néhány évvel ezelótt a szállítók versenyeztetése és a folyamatos nyomásgyakorlás volt inkább az alkalmazott eszköztár legjelentôsebb eleme.

7 „A Szegedi Tudományegyetem lehetőségei a tudásalapú helyi gazdaságfejlesztésben” címú kutatás során készült empirikus felmérés alapján. Ezúton is szeretnék köszönetet mondani egyrészt Prof. Dr. Lengyel Imre kutatásvezetônek, aki bevont a kutatómunkába, másrészt Bajmócy Zoltán és Deák Szabolcs kollégáimnak, akik az egyéb szükséges információkat rendelkezésemre bocsátották.

${ }^{8}$ Ez a kutatás a Regionális Operatív Program 3.3.1.-05/1.-200508-0002/34. számú projektjének kereten belül zajlott.

9 Ezek: a Csongrád Megyei Kereskedelmi és Iparkamara, a Progress Vállalkozásfejlesztési Alapítvány, a DARFT Regionális Fejlesztési Ügynökség, az ITDH, illetve más a válaszadó által megjelölt vállalkozásfejlesztési szolgáltatásokat biztosító szervezet.

10 A kérdő́ivben az alábbi szervezetek szerepeltek: Csongrád Megyei Kereskedelmi és Iparkamara, illetve a GYOSZ, a KIOSZ és a VOSZ Csongrád megyei szervezetei.

\section{Felhasznál irodalom}

ADAPT (2001): Learning Networks. Small firms co-operating to compete. ADAPT, Brussels

Brito, C.M. (2001): Towards an institutional theory of the dinamics of industrial networks. Journal of Business \& Industrial Marketing, 3, pp. 150-166

DG ENTR (2004): SMEs and cooperation. DG ENTR, Brussels

Drakopoulou Dodd, S. - Patra, E. (2002): National differencesin entrepreneurial networking. Entrepreneurship and Regional Development, 14, pp. 117-134

Elfring, T.-Hulsink, W. (2003): NetworksinEntrepreneurship: The Case of High Technology Firms. Small business Economics 21, pp. 409-422

Ford, D. (2003): Business Marketing. KJK-KERSZÖV, Budapest
Gereffi, G. (1999): International trade and industrial upgrading in the apparel commodity chain. Journal of International Economics, 48, pp. 37-70

Hancé, B. - Cieply, S. (1996): Bridging the Finance Gap for Small Firms. Social Science Research Center, Berlin

Hansen, E.L. (2000): Resource Acquisition as a Startup Process: Initial Stocks of Social capital and Organizational foundings. In Reynolds, P. - Bygrave, W. - Birley, S. - Butler, J. - Davidsson, P. - Gartner, W. - McDougall, P. (Eds.): Frontiers of Entrepreneurship Research Wellesley, MA: Babson College

Häkansson, H. - Snehota, I. (1995): Developing Relationships in Business Networks. Routledge, London

Hills, G.E. - Lumpkin, G.T. - Singh R.P. (1997): Oppurtunity Recognition:PerceptionsandBehaviorsofEntrepreneurs. In Reynolds, P. - Bygrave, W. - Birley, S. - Butler, J. - Davidsson, P. - Gartner, W. - McDougall, P. (Eds.): Frontiers of Entrepreneurship Research Wellesley, MA: Babson College

Huggins, R. (2000): The success and failure of policyimplanted inter-firm network inititatives: motivations, processes and structure. Enterpreneurship \& Regional development, 12, pp. 111-135

Humphrey, J. - Schmitz, H. (2002): Developing Firms in the World Economy: Governance and Upgrading in Global Value chains. INEF Report, University of Duisburg, Duisburg

Imreh Sz. - Lengyel I. (2002): A kis- és középvállalkozások regionális hálózatainak foóbb jellemzói. In Buzás $\mathrm{N}$. - Lengyel I. (szerk.): Az ipari parkok fejlődési lehetőségei. SZTE GTK, JATEPressz, Szeged, 154-174. o.

Johannisson, B. - Ramirez-Pasillas M. (2001): Networking for Entrepreneurship: Building a Topography Model Of Human, Social and Cultural Capital. In Reynolds, P. - Bygrave, W. - Birley, S. - Butler, J. - Davidsson, P. - Gartner, W. - McDougall, P. (Eds.): Frontiers of Entrepreneurship Research Wellesley, MA: Babson College

Johannisson, B. (1997): The Dynamics of Entrepreneurial Networks. In Reynolds, P. - Bygrave, W. - Birley, S. - Butler, J. - Davidsson, P. - Gartner, W. - McDougall, P. (Eds.): Frontiers of Entrepreneurship Research Wellesley, MA: Babson College

Kállay L. (2000): Mikrohitelezés piaci alapon. Közgazdasági Szemle 1. 41-63. o.

Kállay L. - Imreh Sz. (2004): A kis- és középvállalkozás-fejlesztés gazdaságtana. Aula, Budapest

Kingsley, G. - Malecki, E.J. (2004): Networking for Competitiveness. Small Business Economics 23, pp. 71-84.

Kocsis É. (2000): Új szervezeti formák a modern kapitalizmusban. In: Bara Z. - Szabó K. (szerk.): Gazdasági rendszerek, országok, intézmények: bevezetés az összehasonlító gazdaságtanba. Aula, Budapest, 467-515. o.

Lechner, C.- Dowling, M. (2003): Firm networks: external relationshipsassourcesforthegrowthandcompetitiveness of entrepreneurial firms. Entrepreneurship and Regional Development, 15, pp. 1-26 
Malecki, E.J. (1997): Technology and Economic Development: The Dynamics of local, regional and national competitiveness. Longman, Edinburgh

Mäkinen, H. (2002): The Genesis and Development of a New Innovation Network in Finland. Turku School of Economics and Business Administration, Turku

Mundim, A.P.F. - Rossi, A. - Stocchetti A. (2000): SMEs in Global Market: Challenges, Oppurtinities and Threats. Brasilian Electronic Journal of Economics

OECD (2004): Networks, Partnerships, Clusters and Intellectual Property Rights: Opportunities and Challenges for Innovative SMEs in a Global Economy. OECD, Paris

Patik R. (2004): A társadalom és a kultúra hatása a hálózatosodásra. In Garai L. - Czagány L. (szerk.): A szociális identitás, az információ és a piac. JATEPress, Szeged, 168-165. o.

Patik R. (2006): „Látható kéz” és innováció - olasz iparági körzetek ma. Vezetéstudomány 11, 22-32. o.

Pietrobelli, C. - Rabelotti, R. (2004): Competitiveness and Upgrading in Clusters and Value Chains. The Case of Latin America. DTI/UNIDO Competitiveness Conference, Pretoria

Premaratne, S.P. (2001): The Impact of Entrepreneurial External Resource Networks os Small Business Growth. USASBE/SBIDA Annual National Conference: An Entrepreneurial Odyssey Orlando, Florida

Propis, L. (2002): Types of Innovation and Interfirm Cooperation. Entrepreneurship \& Regional Development, 14, pp. 337-353

Rickne, A. (2001): Networking and Firm Performance. . In Reynolds, P. - Bygrave, W. - Birley, S. - Butler, J. - Davidsson, P. - Gartner, W. - McDougall, P. (Eds.): Frontiers of Entrepreneurship Research Wellesley, MA: Babson College
Rosenfeld, S.A. (2002): Creating Smart Systems. A guide to cluster strategies in less favoured regions. EU DG for Regional Policy and Cohesion, Brussels

Salmi, P. - Blomqvist, K. - Ahola, J. - Kyläheiko, K. (2001): Industrial districts and regional development: Towards a knowledge-based view. Lappeenranta University of Technology

Schmitz, H: (1995): Collective efficiency: Growth path for small-scale industry. Journal of Development Studies, 31, pp. 529-566

Singh, R.P. - Hills, G.E. - Hybels, R.C. - Lumpkin, G.T. (1999): Oppurtunity Recognition Through Social Network Characteristics of Entrepreneurs

Szerb L. (2003): The Changing Role of Enterpreneur and Entrepreneurship of Network Organisation. In Lengyel, I. (ed): Knowledge Transfer, Small and Medium-sized Enterprises, and Regional Development in Hungary. JATEPress, Szeged, pp. 81-95.

Varamäki, E. - Pihkala, T. (1997): A hotel of small firms - An oddity of SME-networking. Journal of Best Papers Proceedings of ICSB Conference, San Francisco, USA

Varamäki, E. (1996): The development process of interfirm cooperation of SME's. In Reynolds, P. - Bygrave, W. - Birley, S. - Butler, J. - Davidsson, P. - Gartner, W. - McDougall, P. (Eds.): Frontiers of Entrepreneurship Research Wellesley, MA: Babson College

Veres Z. (1998): Szolgáltatásmarketing. Múszaki Könyvkiadó, Budapest

Vilmányi M. (2004): Szervezeti tanulás, hálózati kompetencia, bizalom. In Garai L. - Czagány L. (szerk.): A szociális identitás, az információ és a piac. JATEPress, Szeged, 186-200. o.

Cikk beérkezett: 2007. 6. hó

Lektori vélemény alapján átdolgozva: 2007. 10. hó 